\title{
Towards Improving the Quality of Basic Education in Ghana. Teacher Licensure and Matters Arising: Challenges and the way Forward
}

\author{
Ronald Osei Mensah \\ Ph.D. Candidate, University of Cape Coast (UCC) \\ College of Humanities and Legal Studies, Faculty of Social Sciences \\ PMB Department of Sociology and Anthropology \\ Andrews Acquah \\ Assistant Lecturer, School of Education \\ Valley View University, P.O.Box AF 595, Adentan, Accra \\ Ghana \\ Dr. Agyemang Frimpong \\ Lecturer, Ghana Institute of Management and Public Administration (GIMPA) \\ School of Public Service and Governance \\ Department of Public Management and International Relations \\ P. O. Box AH 50, Achimota-Accra \\ Ghana \\ Pearl Adiza Babah \\ Tutor, Department of Social Science \\ Accra College of Education, P. O. Box 221 Legon, Accra \\ Ghana
}

\begin{abstract}
Quality basic education is the one of the most important educational institutions that influences and is influenced by other educational institutions. The instrumental role played by basic education in developing human resources for both personal fulfilment and social advancement has been recognized in the world over. The general objective of this paper is to review literature and making discussions on the challenges encountered in the Ghana National Teachers' Licensure Examination.It is obvious that even though the works reviewed, the challenges and the ways forward for the licensure examination were not in the Ghanaian setting, the challenges found in other areas where the teacher licensing examination is conducted annually are applicable to the Ghanaian setting. Therefore, the search for ways of addressing the challenges will help to improve the quality of basic education in Ghana. We recommend that there is an urgent need for a tripartite collaboration between the Government of Ghana, the Ministry of Education and the National Teaching Council to be able to establish a committee that is responsible for addressing the challenges of the teacher licensure examination in Ghana. This will go a long way to help in addressing the problems or the challenges that arises in the conduct of the teacher licensure examination year by year in Ghana before the challenges become compounded and get out of hands. As the saying goes, "the earlier, the better".
\end{abstract}

Keywords: Teacher licensing, quality education, basic education

\section{Introduction}

According to UNICEF (2000), quality education includes: learners who are healthy, well-nourished, ready to participate and learn and supported in learning by their families and communities, environments that are healthy, safe, protective and gender-sensitive and provide adequate resources and facilities, content that is reflected in relevant curricula and materials for the acquisition of basic skills, especially in the areas of literacy, numeracy and skills for life. In addition, quality education includes knowledge in such areas as gender, health, nutrition, HIV/AIDS prevention and peace, processes through which trained teachers use child-centred teaching approaches in a well-managed classrooms and schools and skillful assessment to facilitate learning and reduce disparities as well as outcomes that encompass knowledge, skills and attitudes, and are linked to national goals for education and positive participation in society. 
This follows logically thatthe above-mentioned areas cannot be done away with as far the very tents that encompass quality education is concerned. It is an undoubtable fact that basic education is the footing of all education and for the achievement of quality education, there is the urgent need for more attention to be paid on basic education.

History records that, there have been certain measures to improve quality of education in the country since independence. Quality basic education is one of the most important educational institutions that influences and is influenced by other educational institutions. The instrumental role played by basic education in developing human resources for both personal fulfilment and social advancement has been recognized in the world over. It has been recognized that the social, economic, political and cultural development of nations depend largely on the quality and level of basic education of their citizens (Rosovesky, 2000). It is therefore established that quality basic education is an engine of development of any country.

Taking notice of the immense role of basic education in national development, both developed and developing nations have undertaken educational reforms in order to make their educational systems functional and relevant to the socioeconomic needs of their citizens. Ghana, a developing country has rolled out several educational reforms to change the structure and content of its educational system to make it suitable to meet the growing developmental needs of the people in the country. One of such new changes is the introduction of teacher licensure examination which was introduced in the year 2018.

\subsection{Problem Statement}

The desire of Ghana to integrate and overhaul the instructor and educational system by licensing strategies has generated much controversy within the teaching fraternity. The rank and file of the country's recognized teacher unions have expressed divergent views. Some claim it is the deliberate effort by a government to punish teachers under the pretext of bad performance by the students. Other school of thoughts are of the view that it is a strategy to reduce teachers to save and protect government's purse. A community of teachers concerned in Ghana has branded the licensing of teachers in Ghana as meaningless since the qualifications earned by school teachers are ample evidence that teachers are already professionals. There is proof in these claims that demonstrate that the success of students in public schools at the fundamental level has been declining year after year over the past decade, and teachers tend to ignore that.

It is necessary to remember that training teachers is not a recent phenomenon as they are taught both in the Western world and certain areas of Africa. Additionally, teachers could have shortcomings, and if not handled correctly until the certificate is issued, that may impact their efficiency and professional life in general. This might build the policy's inability to acknowledge problem. Government wants to provide teachers a chance to deliver their comments and suggestions. Such comments could form the structure for policies to be more accommodating and appropriate to all educational stakeholders. In Philippines, the Professional Teaching Certificate Advice (2014) described one benefit of licensing as work protection in teaching. This is because for professionally licensed teachers the teaching profession is more secure than many other fields. However, if care is not taken and the necessary consultations are not carried out, teachers in Ghana may misunderstand and misinterpret the licensure. Since the introduction of the teacher licensure examinations in Ghana, it has been bedevilled with numerous challenges.

The aim of this paper is to review literature and making discussions on the challenges encountered in the Ghana National Teachers' Licensure Examination. However, in our walk around, we would like to take cognizance of the following; meaning of teacher licensure examination, the policies related to teacher licensing exams in Sub-Saharan Africa, and importance of teacher licensure examination. It is when the above areas have been comprehensively digested that attention would be paid to the challenges of the teacher licensure examinations and the way forward.

\subsection{Objectives of this paper}

The general objective of this paper is to review literature and making discussions on the challenges encountered in the Ghana National Teachers' Licensure Examination. This paper has been written by authors to specifically achieve three main objectives.

The paper aims at systematic review to find out;

i. The policies relating to teaching in Sub-Saharan Africa Countries

ii. The benefits of teacher licensure examination and;

iii. The challenges confronting teacher licensure examinations 


\subsection{Significance of the Study}

This paper will be relevant at the international, national and local levels. It will bring out the various modalities of teacher licensing exams in sub-Saharan Africa, the benefits of teacher licensure exams and the challenges as well as recommendations. This will thereby serve as a theoretical literature and a guide document to any individual who want to do research in same or related area. It will also serve as an empirical document to teacher trainees, graduates, colleges, universities and other relevant stakeholder institutions. Last of all, the paper adds to the body of knowledge.

\section{Literature Review}

\subsection{Definition of Teacher Licensure Examination}

Teacher licensure examination can be defined as a form of paper test taken by qualified teachers to be able to earn the opportunity that makes the teacher a member of a larger network of accomplished educators shaping the profession (Darling-Hammond and Snyder, 2000). It demonstrates the equivalent of a four-year education degree which shows that a teacher has met all standards required for the profession and would elevate the educator to a truly learned profession (National Board for Professional Teaching Standards, 2015). This implies that licensing is an important element to assure quality in the teaching workforce. It establishes the clear distinctions between those who have the desired level of competence to begin practice and those who do not. Many professions use licensing systems to select individuals into their fields and to prevent those considered incompetent from practicing. Licensing system is a measure of knowledge of basic skills, subject matter, and how to teach (Mitchelland Barth, 2001).

In addition, one great benefit of licensure or teaching certification is job security. The teaching profession is more secure than many other fields, especially for certified or professionally licensed teachers (Professional Teaching Certification Advice, 2014). Licensure is the mark of a professional, it is an important requirement for any profession such as the law, medicine, nursing and teaching. Aquino and Balilla (2015) maintained that most countries in the world require trained teachers from the colleges of education or universities to pass the mandated licensure examination before they are considered "highly qualified" and eligible for employment as teachers and be conferred the title of being a professional teacher.

It follows that, just like the nursing profession in Ghana, the teaching profession in other countries demand that a teacher passes licensure examination before he or she is given the green light to translate the curriculum into teaching and learning process. For Kent (2015), it is a standard recognized by employers and their clients, by governments and by the public as an assurance of dedication, skill and quality. It can be deduced from the above that teacher licensure examination is very instrumental in improving the quality of basic education in Ghana. This is because such a license transposes the basic education teachers to express themselves with the highest levels of professionalism though positive character and maintain cordial relationship among themselves and the pupils, they are teaching devoid of any current or future problems.

\subsection{Policies Related to Effective Teaching in Sub-Saharan Africa (Teacher Professionalism)}

\subsubsection{Benin}

\section{National Registration/Professional Guidelines}

Benin is deprived of adequate qualified and certified teachers just like their African colleagues in South of the Sahara. In an attempt to change the fortunes of education in the country, Benin, in 2008, embarked on a drive to improve the qualifications of community teachers to national standards and also recruiting qualified teachers. Unfortunately, two years down the lane, government calculations in 2010 showed that a whooping $9.4 \%$ of schools still had no qualified teachers with Certificat Elementaired' Aptitude Pedagogique (CEAP) nor Certificatd' Aptitude au Professorat de l' Enseignement General (CAP). It was found out that about 50\% of primary schools, and $27 \%$ of secondary schools had qualified teachers. Only $11 \%$ percent of schools had all qualified teachers (Republic of Benin Ministry of Education, 2013).

\section{Pre- /In-Service Training and Student Teaching}

Teacher Education Students in Benin, attend teacher training colleges for two years and graduate with either CEAP or CAP. When government decided to increase the number of trained and professional teachers in 2008, teachers who were already teaching were given the opportunity to obtain a CEAP through a combination of distance learning, as well as face - to - face instructions for a three-year period. 
$80 \%$ of the 9,979 primary school teachers successfully completed the course of training in October, 2011 and were awarded CEAP. Training for secondary school teachers then started in 2013.

The highest number of students that the country's teacher training colleges could train in a year was 1,500. This number represented about $3.6 \%$ of the primary school teacher workforce. The government gave financial support to teacher education students and $45 \%$ of them had scholarship for the first year while $62 \%$ received scholarship in the second year. The government decided to reduce the first-year scholarship to $10 \%$ in 2014 , so that all second-year students (100\%) could receive financial aid.

There was the organisation of 'Continuing Professional Development Training' around school districts made up of four or five schools. Education instructions for primary schools centred on issues identified by the supervisors of the schools. Educators in specific subjects offered instructions for secondary school teachers on professional development and other themes identified at the national level. Though the professional development agenda is aimed at implementation, this implementation most of the time becomes a challenge and the desired result is not always achieved.

\subsubsection{Burkina Faso}

\section{National Registration/Professional Guidelines}

Civil servants' teachers in Burkina Faso are required to obtain a CAP qualification to be able to teach at the primary school. To qualify for this two - year program, one must be a secondary school graduate with good results. Teachers who have CAP and have three years teaching experience are qualified to teach at the secondary level. Those with bachelor's degree can sit for a one to two-year program to obtain Certificatd' Aptitude au Professorat de l'Enseignement Secondaire to enable them teach at the secondary school. Teachers who aspire to the positions of Headteacher, inspector, or advisor on pedagogy, calls for additional coursework.

This coursework entails l'Ecole Normale Superieur de l'Universite de Koudougou. However, the fees for this upgrade is high and a lot of teachers are unable to afford the high cost as well as the time constraints involved in travelling up and down in the pursuit of these qualifications. To get teachers to satisfy the educational needs of the country, a large number of contract workers were hired. This number represents about $60 \%$ of the primary and secondary workforce. These teachers were not mandated to possess the same certification as their civil - servant counterparts mentioned earlier.

\section{Pre-/In-Service Training and Student Teaching}

While $95 \%$ of civil service primary school teachers obtained training to meet certification standards, only $48 \%$ of secondary school teachers achieved that feat as of the 2012 school year (UNESCO Institute of Statistics, 2014). Civil service teachers were only $40 \%$ of the entire teaching workforce. Though the national requirement for teacher certification is high, the pre-service education and training given are largely pedagogical and theoretical with very little or no practical aspects. The 2000 to 2009 national reform program made provisions for inspections, seminars and inservice training to teachers in order to award them certification. Unfortunately, this laudable arrangement could not be implemented.

\subsubsection{Ghana}

\section{National Registration/Professional Guidelines}

Ghana has for some time now introduced 'teacher licensure exam' to give license to graduates of the colleges of education and universities that offer teacher education after their diploma or degree courses. This exam is conducted by the National Teaching Council (NTC). The first exams which covered literacy (verbal aptitude and essay writing), numeracy (basic calculations), and essential teaching skills (methodology) was taken from 10th - 12th September, 2018. The candidate's chances for being hired as teachers of the Ghana Education Service (GES), depended on their ability to pass the licensure exams. University graduates with bachelor's degree in a specific field but untrained, needed a year teacher training program to obtain a 'Postgraduate Diploma in Education'. Certification programs are available for teachers who are already practicing without certification but are willing to obtain one. 


\section{Pre- /In-Service Training and Student Teaching}

The 41 colleges of education offer Diploma in Basic Education (DBE) courses within a three-year period to students who have completed and passed their secondary school exams with a minimum aggregate of 24.This professional teaching certification course is also available to practicing teachers who possess Teacher's Cert ' $A$ ' for a duration of two years. The DBE enables teachers to teach at the basic level; Primary and Junior High Schools (JHS). The Bachelor of Education (B. Ed) degree obtained from the University of Cape Coast (UCC) and the University of Education, Winneba (UEW) give teachers the opportunity to teach in Senior High Schools (SHS). The duration for the degree programs is four (4) years but the DBE certificate, one can obtained in two (2) years (Bediako and Nti, 2014).

The colleges of education and the universities offering teacher education in consonance with the National Teaching Council are required to add to their curriculum 'student teaching'. Teacher trainees are supposed to spend the last year of their program in a basic school or SHS and learn to teach with 'planned mentoring and coaching'.

To deal with the issue of untrained teachers, the Ministry of Education, has rolled - out a four-year Untrained Teacher Diploma in Basic Education (UTDBE), which has succeeded in training 16,000 teachers through distance education (Ghana Education Service, 2012). The Ministry has also put in place an In-Service Education Training (INSET) program for 'continuing professional development' with elements that focus on the school, cluster, and district levels to increase the capacity of teaching and school management.

\subsubsection{Kenya}

\section{National Registration/Student Guidelines}

The Teachers Service Commission was established by the Constitution of Kenyan in 2010, and it was charged with teacher management which includes teacher entry standards and registration. Qualified teachers are supposed to register with the Teachers Service Commission. In 2012, the Kenyan government realized that a vast majority of qualified teachers have not been certified. To increase the pace of certifying all qualified teachers, the Teachers Service Commission set up an online certification process to augment the existing system. For teachers to be considered qualified, they must earn their certificates from Primary Teacher Training Colleges or Diploma Training Colleges. Kenyan National Examination Council certifies the quality of these certificates. To teach in the secondary school requires a bachelor's degree which must be obtained from one of the universities in Kenya (Kenya Ministry of Education and Ministry of Higher Education, Science Technology, 2012).

\section{Pre- /In-Service Training and Student Teaching}

The type of teachers' certificate demanded determines the duration of the course. Every year about 10,000 teachers graduate from the Primary Teacher Training program, while about 12,000 teachers graduate from Diploma Teacher Training Colleges. These courses take three (3) years to complete. The instructions given to secondary school teachers in their quest to obtain a bachelor's in education degree include pedagogy and practical training. Those who take other degrees either than education will need to take a nine - month postgraduate diploma course in education to become certified teachers.

Though it is evident that practical training and student teaching are more important than classroom theory alone, teacher training programs do not have any specific number of practical exercises or experiences that teacher trainees must meet (Kenya Ministry of Education and Ministry of Higher Education, Science Technology, 2012). 18,000 contract teachers were hired in 2009 to augment the teaching workforce. This move increased the teacher population by $8.7 \%$ but did not go done well with the civil service teachers whose unions embarked on a strike to register their displeasure(UNESCO Institute of Statistics, 2014). To remedy the situation, a six - month course was organised on distance learning basis to get the uncertified recruits certified. There is however, one problem with the issue of 'teacher educator'. It appears there is no specific criterion set for an individual to qualify to become a teacher educator.

\subsubsection{Mali}

\section{National Registration/Professional Guidelines}

In the year 2000, Mali established the Institutes de Formation des Maitres in each of its 17 regions to provide a two - to four - year teacher training program for teachers with baccalaureate andwho wish to teach in the primary schools. Their colleagues who desire to teach in the secondary schools require a four - year degree from the University of Bamako. 


\section{Pre- / In-Service Training and Student Teaching}

The training regime for teacher in Mali is comparatively low. Certified civil service teachers make up 20\%, and 30\% of teachers hired are supported by the local community in rural areas, while the rest of the $50 \%$ are contract workers who are hired to teach without possessing the required training or certification.

\subsubsection{Mozambique}

\section{National Registration/Professional Guidelines}

Mozambique's Ministry of Education report in 2009 indicated that $58.5 \%$ of all teachers were contract workers. This is because both trained and untrained teachers start as contract workers until they register through the district government where they are employed, and verified. After verification is done, the district government nominates and forwards the teacher's application to the Administrative court for approval. After approval had been given, the teacher serves a probation of two years before becoming a permanent civil servant. This registration which is supposed to take about six months to complete, can 'linger on' indefinitely rendering teachers 'permanent contract workers'. This delay sterns from two main reasons; lack of funds to pay civil service teachers, and 'red tapism' (Beutel, 2011).

\section{Pre- / In-Service Training and Student Teaching}

There have been several changes in the minimum qualifications required to enter into a teacher training institution and also to practice as a teacher in Mozambique. A few years ago, in order to increase the number of teachers in the country, the two-year teacher certification period was reduced to one year. Teachers who wish to teach at the primary level must have completed $10^{\text {th }}$ grade before attending teacher training institutions, while those who wish to teach in the secondary schools must have completed $12^{\text {th }}$ grade before teacher training.

Pupils enrollment skyrocketed when in 2005 Mozambique abolished the payment of primary school fees. This astronomical increase in pupils enrollment was not backed by educational material provision nor increase in teacher intake. To arrest this anomaly, the Ministry of Education increased the intake of trainees and by 2011 the newly trained teachers have shot up to 8,000 from 4,500 in 2006. While this brought up the level of trained teachers, a large percentage of teachers both in primary and secondary schools still remained untrained. It was realized that in 2004 the untrained teacher population in lower primary, upper primary and lower secondary was $44 \%, 34 \%$, $44 \%$ respectively, however, by 2011 , figure had dropped to $21 \%, 17 \%$, and $21 \%$ respectively yet much work needed to be done to bring the situation to an appreciable level (Republic of Mozambique Ministry of Education, 2012).

To assist with 'continuing professional development', teachers are made to take part in pedagogical days, throughout the school year, when additional instructions are provided to them (with special concentration on reading, writing and effective teaching) and also to share experiences with their peers.Again, In-Service Education and Training (INSET) courses with short duration are available in the teacher training colleges but by 2010 , only $12.6 \%$ of primary school teachers had participated in these courses. The longer continuing professional development programs aimed at certifying or upgrading the qualifications of teachers also exist but are not attractive to teachers since they are expensive and time consuming(Beutel, 2011).

\subsubsection{Niger}

\section{National Registration/Professional Guidelines}

Niger is believed to have one of the stringent certification processes in relation to teaching considering the fact that it has few colleges that offer education degrees. The country has seven (7) EcolesNormalesd'Instituteurs (ENI) that offer Certificat de Fin d'Etudes du Premier Degre, which is a two - year course required to teach primary school. The University of Niamey is the sole institution that offers a four - year Brevet d'Etudes du Premier Cycle program to teach at secondary school, and also for those who have baccalaureate, a three - year program to obtain licensure to teach in secondary schools. As part of the requirement for certification, all teaching candidate since 2010, are require to submit and pass a written thesis. This is to ensure that certified teachers have both verbal and written competencies.

These prerequisite requirements have led to a number of teachers allegedly presenting fake licenses for employment. In 2012, some parents and students went on demonstration in a bid to bring to the attention of the government the issue of so -called 'fake teachers'. 


\section{Pre- / In-Service Training and Student Teaching}

The requirement for certification in Niger is five (5) weeks of guided teaching and six (6) weeks of taking charge of a class. This brings the official number of weeks required to eleven (11). Evidence show that during the certification program, teachers had less than twenty (20) days of student teaching. There is also a 30 - 40-day training certificate program for teachers who are already in the field, organised by the ENI. Surprisingly, only $17 \%$ of teachers in secondary schools have had this training.

\subsubsection{Nigeria}

\section{National Registration/Professional Guidelines}

In Nigeria, programs for teaching certification can be assessed at the National Teachers Institute or any of the state universities. The Nigerian Certificate in Education (NCE) is the minimum qualification required to teach in primary and junior secondary schools. It takes three years to obtain this post-secondary certificate. A bachelor's degree in education or a bachelor's degree in a specific subject plus a Postgraduate Diploma in Education (PGDE) is required to teach in a secondary school.

\section{Pre- / In-Service Training and Student Teaching}

The minimum requirement for teacher certification in Nigeria is set by the National Commission for Colleges of Education (NCE). The commission updated the minimum requirement in 2012 and added guidelines for curriculum content to that of the teacher education institutions. Trainees are required to do twenty-six (26) weeks of teaching practice with a minimum of ten (10) periods and a maximum of eighteen (18) periods per week in the classroom and also receive an evaluation score not less than ten (10) (National Commission for Colleges of Education, 2013).

The National Teachers Institute (NTI) of Nigerian offers courses on distance learning basis in order to give certification to teachers, upgrade their qualifications, and provide them with professional development opportunities. The institute offers NCE, PGDE, and Advance Diploma in Education courses through their study centres scattered across the country including their main facility located at Kaduna.

The institute provides a one - year Pivotal Teachers Training, as well as Technical Teachers Training Programs in order to offer teachers basic level instruction before they complete the NCE which is between three (3) to four (4) years.

The NTI offers continuing professional development programs and workshops through their distance learning modules. Active unions like the Nigerian Union of Teachers are always looking for an opportunity to bring educators together for discussions and seminars. A survey in 15 schools in 2012, showed that $47 \%$ of teachers say they have not had the opportunity to take part in an in-service Education and Training (INSET) before.

\subsubsection{South Africa}

\section{National Registration/Professional Guidelines}

There are two ways through which teachers in South Africa can get accreditation. Would-be teachers may obtain a bachelor's degree in education from an accredited university, or get a bachelor's degree in a specific subject area plus one-year Advance Diploma in Education. Every educator in a public institution as well as teachers who are foreigners must register with the South African Council for Educators (SACE).

\section{Pre- / In-Service Training and Student Teaching}

Potential teachers in South Africa may obtain their pre-service training in two different ways; face-to-face classroom education (full time/part-time), or by distance learning. 480 credit hours and about four years is required to complete any of the two pathways to certification whether with Bachelor's in Education degree, or a bachelor's in a specific field plus an Advance Diploma in Education. As part of the Bachelor's in Education program, students are required to teach many times for shorter periods, or several times for longer periods (South Africa Department of Education, 2007).

In 2012, the South African Council for Educators gave approval for Continuing Professional Teacher Development (CPTD) programs for teachers, deputy principals and principals, with registration and implementation beginning from January, 2014.

SACE also approves continuing education courses through the CPTD system for teacher unions, employers, and nongovernmental organisations (NGOs). In each three-year cycle, educators have a required minimum number of professional development credits they have to meet in order to remain relevant (South African Council for Educators, 2014). 


\subsubsection{Uganda}

\section{National Registration / Professional Guidelines}

Uganda awards teachers certification in three different ways. Whereas the primary school teachers get their certification from the Primary Teacher Colleges, the secondary school teachers get theirs from the National Teachers' Colleges. The universities, however, offer certification for both primary and secondary school teachers. The course duration varies from two (2) to three (3) years and depends on whether it is pre-service, or in-service, and also the kind of teaching award granted, as well as the teaching certificate or degree in education that is pursued (Uganda Ministry of Education and Sports, 2013).

By the year 2006, a total of 6,729 new teachers had been trained by pre-service primary school teacher training institutions. This figure represents $4.5 \%$ of primary school teachers in Uganda. In that same year, teachers who left the service were about 5\% (Mulkeen, 2010).

An average of 8,769 new primary school teachers graduate each year but in the same year about 6,616 abandon the teaching profession. The ministry of Education projects that by 2025, Uganda will need from 15,925 to 22,999 new primary school teachers every year to meet the ever-increasing student population as well as to replace teachers who have left the system (Uganda Ministry of Education and Sports, 2013).

\section{Pre- / In-Service Training and Student Teaching}

Primary school teachers as part of their training program, in the second year, are required to teach for a six-week period on two occasions before they are certified. There is however, no student teaching requirement for the diploma and bachelor's in education degree courses for secondary school teachers. There are laid down procedure to get teachers certified or to upgrade their teaching certificate to a diploma or bachelor's degree after satisfying certain in-service training requirements. Though there appears to be a significant improvement in Uganda's certification drive for its public-school teachers, this achievement is partly attributed to the fact that most of the unqualified teachers move from the public schools to private institutions. The percentage of unqualified teachers in the public primary schools dropped from $11.2 \%$ to $2.7 \%$, while in the private schools the drop has been very marginal; from $34.9 \%$ to $34.6 \%$. The secondary school situation is no different (Uganda Ministry of Education and Sports, 2013).

\subsubsection{Zambia}

\section{National Registration/Professional Guidelines}

The duration of the Zambia Teacher Education course was recently increased from two years to three years. This certification program includes pedagogy, theory, as well as one year of practical teaching experience. The Primary Teachers Diploma started in 2012, while the Secondary Teachers Diploma commenced in 2014. Both programs are available in Zambia's 14 public teacher education colleges. These programs enable untrained teachers who are already teaching to gain certification through distance learning. In 2005, 503 more teachers were given certification as primary school teachers as against the number of teachers that left the system the preceding year (Mulkeen, 2010)

\section{Pre- / In-Service Training and Student Teaching}

The education colleges require that teacher trainees do one (1) year teaching in order to attain the primary school teacher certificate or diploma, one (1) term for the secondary diploma, and five (5) weeks for bachelor's degree candidates (Mulkeen, 2010).

Some colleges of education also offer in-service education and training (INSET) in the form of seminars and workshops, but since they are not on regular basis, their attendance become a challenge to some teachers especially those in the rural areas. With the assistance of international organisations, school districts in Zambia, are involved in projects that would enhance the use of technology for teacher training and development.

\subsection{Benefits of Teacher Licensure Examination}

It can be directlyobserved that passing the licensure examination for teachers is an effective indicator of teacher quality in achieving quality basic education in Ghana. In line with this, Buddin andZamaro(2008) expressed that since licensure tests are designed to set minimum teaching proficiency standards, potential teachers who fall below the pass mark scores on the licensure examination for teachers might indeed have worse classroom outcomes than teachers who ultimately achieve the pass mark or even marks above the pass mark. By understanding how teacher qualifications are most strongly related to academic success, it is imperative that educators meet all standards required for the profession through acquisition of a professional license. 
This aligns with the analysis of Mckinsey (2010) which asserted that the quality of an education system cannot exceed the quality of its workforce which also serves as one of the most widely quoted springboards for policy reform by both policy makers and teacher organisations.

Licensure examination for teachers is considered important by teacher educators of basic education in theirprofessional development. It also gives them not only honour and prestige but a competitive advantage over those who are nonlicensure examination teachers (Aquino and Balillia, 2015). Taking into consideration, the importance of eligibility to the teaching profession, getting a good pass in thelicensure examination for teachers makes professional teachers who are highly qualified and eligible for employment as teachers both in private and public schools. The government, therefore, has a role to regulate the teaching practice by requiring aspiring teachers to register, write and pass the licensure examination before they are accepted into the teaching profession. Studies reveal that licensed or certified teachers are found to produce stronger student achievement gains than do uncertified teachers (Darling-Hammond, Holtzman, Gatlin and Heilig, 2005).

Alexander and Fuller (2004) indicate that certified teachers are associated with increased student achievement. Vandevoort and Berliner (2004) stressed that teachers who passed the licensure teacher examinations are, on average, more effective teachers in terms of academic achievement. Goldhaber and Brewer(2000) also agreed and found that students taught by fully certified mathematics and science teachers had greater gains in student scores than students taught by teachers with emergency. Additionally, Goldhaber and Anthony (2007) indicated that National Board for Professional Teaching Standards certified teachers were more effective than their non-certified counterparts at increasing student achievement. Now that we have been able to comprehensively put up discussions of teacher licensure examination and its importance, we would like to shift our attention to the challenges of teacher licensure examination.

\subsection{Challenges Facing Teacher Licensure Examination and the Way Forward}

In this section of the paper, we would pay attention to reviewing literature on the challenges of teacher licensure examination and the way forward. It must be established that we would pay attention to reviewing empirical literature to achieve the objective of this section of the write-up. Sadiq and Saeed (2017) explored the challenges encountered by teachers during licensure examinations for teachers in Pakistan. Specifically, their study sought to find out the problems teachers encounter during licensure teacher examination regarding the following namely; the physical environment, management and conduction of exams and technical errors of the examination board. Their study was qualitative in nature and was a descriptive research. Their study selected ten teachers by using convenient sampling technique. Interview protocol was used as a research instrument and survey method was adopted for data collection. Interviewees' consent was taken before conducting the interview.

The researchers discussed the instrument with relevant experts to validate it. After discussion with experts, irrelevant questions were discarded, after that, research instrument was finalized and data was collected. The interview data were tap recorded, transcribed and themes were generated in line with the specific objectives and the research questions. The study found out that the challenges regarding the physical environment were; electricity problem, insufficient furniture and overcrowded rooms. In line with these challenges it was found out that challenges regarding the management and conduction of the exams were; invigilation issues, interruption during exams, non-cooperation behaviour of examination board authorities, late delivery of question papers, improper sitting plan and leakage of examination questions. For the challenges regarding technical errors, the following were found; issuance of roll number slips, issues with online registration processes and printing mistakes.

The following suggestions were given by the teachers in addressing the challenges they encountered during the licensure examination for teachers. These suggestions were; there is the need to provide the teachers with conducive environment during the exams, examination board staff should be circumspect in their behaviour towards teachers who are taking licensure examination and there is the need for the examination body to be cooperative in their attitudes. Additionally, it was suggested that examination boards must realize the sensitivity of this pity issues to keep the student's morale high and to promote the quality education among students. The students demand comfort and ease regarding access to and up to date examination system during their examination. Most importantly, on the part of the examination board to provide the solution to the students' problems regarding exams is not only a matter to enhance the quality education but it makes the students' performance better. Intensive training may be given to the invigilation staff to avoid the inconvenience for students at examination centres. They should be briefed about all the guidelines they need to observe and the instructions given to students which they need to follow while attempting the papers. Invigilators must be vigilant and more IT skilled staff may be hired by the examination boards to avoid the technical errors. 
Sañosa- Aljo and Tancinco (2016) sought to conduct a study on the topic: 'faculty performance and students' academic achievement in the licensure examination for teachers of Naval State University'. The main objective of the study was to ascertain the faculty members performance and students' academic achievement in the licensure examination for teachers of Naval State University. As part of their specific objectives, the researchers sought to identify the challenges encountered by the faculty members and the students in preparation for the Licensure Examination for Teachers (LET). Descriptive survey was employed for the study. The sample population for the study was 62 College of Education (COED) Faculty members and 1,072 students who took the Licensure Examination for Teachers (LET). In order to achieve the stated specific objective, questionnaire was employed. Data collected was analysed using descriptive statistics such as the mean, percentage and frequency counts. It was revealed from the study that problems encountered by faculty in preparation for the Licensure Examination for Teachers by faculty members included; insufficient review materials and books, difficulty by the students to comprehend, financial constraints faced by students, no core group to conduct review classes to the students, student's lack of focus during lectures, student's willingness to learn during class lecture, curriculum was not well-organized in the library, less updates on development of the examination, lack of professional preparations of reviewers, lack of support from parents, lack of competency guide on major courses, and overloaded faculty members. Results revealed that the most common problem observed by the faculty members in preparation for licensure examinations was insufficient/inadequate books and review materials.

On the other hand, the study also revealed that problems encountered by the students in preparation for the Licensure Examination for Teachers were; insufficient review materials, Insufficient time to focus in the review, financial problems, difficulty to understand the content, inability to enrol in review classes, lack of emotional and psychological preparedness, irrelevant review materials, attitude problem, inconsistent answers in the review materials, some graduated several years passed, change of curriculum, health problems and overconfident.

\section{Conclusion and recommendations}

In conclusion, this paper has been able to achieve the aim of discussing comprehensively the challenges and the ways forward for the teacher licensure examination in Ghana. It can be deduced from the above that even though the works reviewed as far as the challenges and the ways forward for the licensure examination were not in the Ghanaian setting, the challenges found in other areas where the teacher licensing examination is conducted annually are applicable to the Ghanaian setting. Therefore, the search for ways of addressing the challenges will help to improve the quality of basic education in Ghana.

In order to overcome the above challenges, the researchers recommended that activities related to the licensure examination for teachers may be institutionalized like the conduct of qualifying exams, pre-board exams and mock examinations. Secondly, refresher courses must be integrated in special topics which will be handled through team teaching.

In addition, it was recommended that parallel study may be conducted to revalidate the findings of the present study. Other researches may also be performed which will include variables not employed in this study like the age of school, accreditation level and the non-cognitive factors of the licensure examination for teacher takers.

Finally, there is an urgent need for a tripartite collaboration between the Government of Ghana, the Ministry of Education and the National Teaching Council to be able to establish a committee that is responsible for addressing the challenges of the teacher licensure examination in Ghana. This will go a long way to help in addressing the problems or the challenges that arises in the conduct of the teacher licensure examination year by year in Ghana before the challenges become compounded and get out of hands. As the saying goes, "the earlier, the better".

\section{Acknowledgement}

Authors would like to thank reviewers for their insightful contribution towards the paper.

\section{References}

Asare, K. B.,and Nti, S. K. (2014). Teacher education in Ghana: A contemporary synopsis and matters arising.SAGE Open, 4(2), 1-8.

Aquino, A., and Balilla, L. (2015). Pre-service teachers' licensure examination plans and content knowledge.Asia Pacific Journal of Education, Arts and Sciences,2(2), 110-116.

Beutel, M. (2011). Teachers talking: Primary teachers' contributions to the quality of education in Mozambique. Research Report, Kingston upon Thames: VSO International. 
Buddin, R., and Zamarro, G. (2008). Teacher quality, teacher licensure tests, and student achievement. Santa Monica, CA: RAND.

Conable, C. (1988). The case for universal basic education for the world's poorest boys and girls.New York: Author.

Darling-Hammond, L., and Snyder, J. (2000). Authentic assessment of teaching in context. Teaching and Teacher Education, 16(6), 523-545.

Darling-Hammond, L., Holtzman, D. J., Gatlin, S. J., and Heilig, J. V. (2005). Does teacher preparation matter? Evidence about teacher certification, teach for America, and teacher effectiveness. Education Policy Analysis Archives, 13(42), 42-51.

Ghana Education Service (2012). Pre-Tertiary Teacher Professional Development and Management in Ghana.Ministry of Education, January 31.

Goldhaber, D. D., and Brewer, D. J. (2000). Does teacher certification matter? High school teacher certification status and student achievement. Education Evaluation and PolicyAnalysis, 22, 129-145.

Goldhaber, D., and Anthony, E. (2007). Can teacher quality be effectively assessed? National board certification as a signal of effective teaching. The Review of Economics andStatistics, 89(1), 134-150.

Kent, J. (2015). The power of PE license. Retrieved from https://www.monster.com

Mitchell, R., \&Barth, P. (2001). How teacher licensing tests fall short. Thinking K-16(1), 3-21.

Mulkeen, A. (2010). Teachers in Anglophone Africa: Issues in teacher supply, training, and management. Washington, DC: The World Bank.

National Board for Professional Teaching Standards (2015). About certification, elevating teaching, empowering teachers. Retrieved from http://www.boardcertifiedteachers.org

National Commission for Colleges of Education(2013). NCCE Online. Retrieved from www.ncceonline.edu.ng.

Professional Teaching Certification Advice (2014). Benefits of teachingcertification.Retrieved fromhttp://www.teachingcertificationhelp.com

Kenya Ministry of Education and Ministry of Higher Education, Science Technology (2012). A policy framework for education and training. Sessional Paper, Nairobi: Republic of Kenya.

Republic of Benin Ministry of Education (2013). Plan decennal de developpement du secteur de l'educationactualise phase 3/2013-2015. Sector Plan, Cotonou: Government of Benin.

Republic of Mozambique Ministry of Education (2012). Education strategic plan: 2012-2016. Strategic Plan, Maputo: Republic of Mozambique.

Rosovesky, C. (2000). Improving quality education. Oxford Economic Papers, 58, 450-474.

Sadiq, A., and Saeed, M. (2017). Challenges encountered by teachers during licensure examinations for teachers in Pakistan. Bulletin of Education and Research, 39(1), 101-115.

Sañosa- Aljo, G., andTancinco, N. P. (2016). Faculty performance and students' academic achievement in the licensure examination for teachers of Naval State University. Journal of Research and Method in Education, 6(4), 1-10.

South Africa Department of Education (2007). The national policy framework for teacher education and development in South Africa.Government Gazette, 3-30.

South African Council for Educators (2014).Continuing professional teacher development handbook. Centurion: South African Council for Educators.

Uganda Ministry of Education and Sports (2013).Teacher issues in Uganda: A diagnosis for a shared vision on issues and the designing of a feasible, indigenous and effective teachers' policy. Government Report, Kampala: Government of Uganda.

UNESCO Institute of Statistics (2014). UNESCO Institute of statistics data centre. Retrieved from http://data.uis.unesco.org.

UNICEF (2000). Curriculum report card. Working Paper Series, Education Section, Programme Division. New York: Author. 